\title{
Review on village/backyard/ poultry production system in Ethiopia
}

\author{
Shukurala Chaimiso \\ Gombora Woreda Livestock and Fishery Resource Development Office, South Nation Nationalities and People Regional \\ State, Ethiopia \\ *Correspondence: shukuralachaimiso@gmail.com
}

\begin{abstract}
A review was undertaken to obtain the related research results and facts on village/backyard/ poultry production systems in Ethiopia with the aim of bringing synthesized andsummarized information to the beneficiaries. Poultry production has a major role in poverty alleviation by means ofincome generation and household food security. Village/backyard/ chicken production system is characterized by low input andoutput scavenging, with minimal investment in housing, feeding, watering and chicken health management systems. The village chicken production system in Ethiopia is extensive anddominated by indigenous chickens that exhibit remarkable adaptation to local environments. Generally, it is concluded that thevillage/backyard/ chicken production system offers many people the opportunity to improve theirlivelihoods, suggesting that improvement of chicken management system, breeding, production environment, farmers' access to inputsand markets needs to focus on the back yard chicken production system.
\end{abstract}

Keywords: backyard poultry, poultry production, Ethiopia

\section{Introduction}

Livestock production in general and chickens in particular play important socioeconomic roles in developing countries $^{[3] ;}{ }^{[42]}$. Poultry production has a major role in the economy of developing countries, including an important role in poverty alleviation by means of income generation and household food security ${ }^{[14] ;}{ }^{[19]}$ and ${ }^{[1]}$. Provision of animal protein, generation of extra cash incomes and religious/cultural considerations are amongst the major reasons for keeping village chickens by rural communities ${ }^{[3]}$. Nearly all rural and peri-urban families in developing countries keep a small flock of free range chickens ${ }^{[24]}$.

Village chickens are also an integrated component of nearly all rural, many peri-urban and some urban households and accounts for more than $60 \%$ of the total national chicken population in most African countries [7]; [46]. According to[40] and $^{[45]}$ reports; small farming families, landless laborers and people with incomes below the poverty line were able to raise village birds with low inputs and harvested the benefits of eggs and meat via scavenging feed resources. However, most rural communities lack the required husbandry skills, training and opportunity to effectively improve their chicken production ${ }^{[33]}$.

In Ethiopia chickens are the most widespread and almost every rural family owns chickens, which provide a valuable source of family protein and income ${ }^{[47]}$. The total chicken population in Ethiopia is estimated at 49.3 million $^{[9]}$, with $99 \%$ of the population consisting of indigenous breeds reared under village production systems, and the remaining $1 \%$ being exotic breeds reared under intensive management ${ }^{[51]}$. However, Ethiopian ${ }^{[10]}$ reported that $96.9,0.54$ and $2.56 \%$ of the total poultry were reported to be indigenous, hybrid and exotic, respectively. The majority (99\%) of these chickens are maintained under a traditional system with little or no inputs for housing, feeding or health care. The most dominant chicken types reared in this system are local ecotypes, which show a large variation in body position, color, comb type and productivity ${ }^{[53] ;[48]}$ and ${ }^{[21]}$. The greater part of the feed for village chicken isobtained through scavenging, which includes the household cooking wastecereal and cereal by-products, pulses, roots and tubers, oilseeds, shrubs, fruits and animal proteins ${ }^{[43]}$.

More than half of Ethiopian households both in rural and urban areas keep chickens, although there is considerable variation in the distribution of chicken keeping, with most households in highland areas are keeping chickens, and far fewer doing so in lowland pastoral areas ${ }^{[5]}$ and ${ }^{[55]}$. It is difficult to design and implement chicken-based development programs that benefit rural people without understanding village chicken production systems ${ }^{[20] ;}{ }^{[38,22]}$ also reported that understanding of village chicken functioning and marketing structure are a prerequisite for developing market opportunities for rural households and could be used to inform policy makers and development workers in considering the commercial and institutional environment in which village chicken keepers have to operate. 
To improve the productivity of village/backyard poultry production system; having basic knowledge about village poultry production system. However, there is a limitation to reviewing these and other related information and thus to delivering such synthesized and summarized data to the beneficiaries.Therefore, reviewing functional findings on village/backyard/ poultry production system seems to be main area to deliver combined information to the beneficiaries. Based on this outlined background, the objective of this paper was: Review on village/backyard/ poultry production system and thereby to deliver combined information for beneficiaries.

Most of the related research findings of village/backyard/ chicken production system were reviewed. Related reports which focus on housing, flock size, village chicken production, management, feeding and watering practices were also reviewed. Findings on poultry production that have been reported by various scholars were also reviewed and combined.

2. Description of Poultry Production Systems in Ethiopia The poultry sector in Ethiopia can be characterizedinto three major production systems, namely thelarge-scale commercial, the small scale commercial and the village or backyard poultry production system. Each can sustainably coexist and contribute to solve the socio-economic problems of different target societies [49]. The backyard poultry production system is characterized by low input, low output and periodic destruction of large proportion of the flock due to disease outbreaks ${ }^{[48]}$.

\subsection{Village/Backyard/poultry production system}

Village/backyard/ chicken production systems are the techniques under which the birds are unrestricted in their movements except that they are usually shut up at night for protection from predators. Local chicken production is predominantly based on scavenging, a low input and low output production system. Scavenging made up $82.9 \%$ of the production system using a majority $(96.8 \%)$ of local chicken ecotypes, with only seasonal/conditional feed supplementation. ${ }^{[41]}$ and ${ }^{[27]}$ reported that almost $83 \%$ of the total chicken population in Malawi smallholder extensive chicken production system was indigenous chicken eco-types, forming the largest proportion of birds kept. ${ }^{[23]}$ also reported that chicken production systems of Bangladesh depend mainly on locally scavenging chickens that were reared in villages and they constituted more than $70 \%$ of the country's chicken population.

Backyard/village/ chicken production is characterized by low input and output scavenging, with minimal investment in housing, feeding and chicken health care management. The system is only partially market- oriented, production being targeted for both household consumption and the open market [16]. The system generally does not involve investments beyond the cost of the foundation stock ${ }^{[54]}$. The majority of village chickens are kept during available feed resource and when the risk of predators is low. Different authors ${ }^{[32]}$ and ${ }^{[12]}$ that there were no cultural/religious taboosagainst consumption and marketing of chicken and eggs in Ethiopia.

\subsubsection{Housing system of backyard/village/ chicken}

Chicken houses constructed from locally available materials, with well-built wall, adequately ventilated with corrugated wire, equipped with watering and feeding materials and provided with litter material was considered as constructed based on the recommended government extension package for poultry housing. The lesser use of recommended specifications in poultry house construction indicates the lack of technical training on scientific poultry rearing to the producers. Generally, it was also observed that few households residing near the town and main road to Addis Ababa provided electricity and litter material in poultry houses. ${ }^{[34]}$ and ${ }^{[52]}$ reported that, the provision of electricity and litter material for village chicken was not practices in most parts of Ethiopia. Both fixed and mobile shedding are common used in backyard/village/ systems. The fixed sheds have litter, perches and nest boxes. However, fixed housing is rarely used in free-range operations, with the most popular system being the use of movable shelters and birds provided an area of pasture in a rotational system ${ }^{[18]}$.

According to ${ }^{[11]}$ finding, from thetotal of 280 chicken owners interviewed, only 62farmers $(22.1 \%)$ prepared separate overnight housesfor village birds. Majority (77.9\%) of village chickenowners kept birds on various night sheltering places including; perches inside the house $(45.7 \%)$ on the floor covered by bamboo made materials $(27.1 \%)$, on ceilings of the house $(3.6 \%)$ and under locally constructed sitting place $(1.4 \%)$. On the other hand, ${ }^{[29]}$ reported that $97.5 \%$ households construct separate house in India for chickens as night enclosure. ${ }^{[35]}$ also reported that $82 \%$ of the households in Zimbabwe provided separate housing for their chicken, while the remaining $18 \%$ had no separate chicken housing.

\subsubsection{Feeding and watering practice of the village/backyard/ chicken}

The dominant system of poultry feeding practiced in Ethiopia is free scavenging with supplementary feeding. However, the proportion of those that supplement their chicks with a

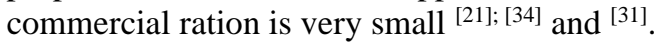

Supplementary feed was provided by majority $(97.5 \%)$ of chicken owners, while $84.3 \%$ of them did this between the months of July to September. Grains and household leftovers were the major kinds of feeds stuffs $(56.4 \%)$ supplemented by chicken owner farmers. Most these chicken owners $(87.1 \%)$ used cereal crop harvest (self-produced grains) as supplementary feed ${ }^{[15,21]}$ also reported that $99.3 \%$ of chicken owners in North West Amhara Region provided supplementary feeds to village birds. Similarly, ${ }^{[29]}$, reported that $95.5 \%$ of the farmers in Rushinga district of Zimbabwe produced their supplementary feeds and only $4.5 \%$ used purchased feed. 
[11] revealed that, about $96 \%$ of respondents were provided water with free access. Likewise, ${ }^{[34]}$ and ${ }^{[32]}$ reported similar, watering practices in Bure district of North West Zone of Amahra region and Jamma district of South Wollo, respectively. All village chicken owners (100\%) of the district provided water to village chickens; $85.4 \%$ only during the dry season and $14.3 \%$ throughout the year. The major sources of water for chicken in the area were river $(30.4 \%)$, spring (28.5\%), locally made underground water $(21.4 \%)$ and pipe water $(19.7 \%)$. Majority of chicken owners (98.2\%) had watering trough. Broken clay material, locally called "shekila", (37.3\%), wooden trough $(32.7 \%)$ and plastic madetrough $(28.2 \%)$ was the most widely used types of watering troughs ${ }^{[11]}$.

2.1.3. Village chicken health and disease care management system

[30] reported that disease was cited as the most important constraint of village chicken production in southern parts of Ethiopia. Newcastle disease (NCD) was the most (98.2\%) prevalent and economically important diseasesproblem affecting free-range birds and it is reportedto be the first major causes of chicken death/loss[15].Similarly, ${ }^{[21]}$ reported that the major causes of death for local birdsin North West Amhara were seasonal outbreaks of diseases, specifically Newcastle disease. The prevalence of the NCD and mortality of chicken were higher at the start of rainy season, mainly on April (66.8\%) and May (31.4\%). [44] also reported that NCD was one of the major infectious diseases affecting productivity and survival of village chickens in central highlands of Ethiopia. Similarly, ${ }^{[26]}$ reported that NCD was identified and accepted as the greatest danger to the expansion of chicken production in Zimbabwe.

Village/backyard/ chicken owners had no any culture of vaccinating birds against diseases in Ethiopia. This might be due to lack of awareness about the presence of chicken vaccines, lack of attention to backyard chickens and low availability of vaccines. A traditional treatment was the major type of treatment used by majority of backyard/village/ chicken owners (95\%) against NCD. Accordingly provision of a mixture of local alcohol ('Arekie'), lemon and onion to sick birds against NCD was the most widely used type of traditional treatment. Other common types of traditional treatments observed were; use some herbs like 'semiza' (Justitia schemperina) and 'endod' (Phytolacca dodecandra) $(33.2 \%)$ and use of tetracycline capsule ${ }^{[15]}$.

\subsubsection{Household labor share for village/backyard/} chicken production

All family members provided labor for village chicken production practices. Men were responsible for few activities like construction of shelter and taking sick birds for treatment. However, women were highly responsible for many activities like cleaning bird's house, feeding birds, selling birds and eggs. Children also participated in various chicken production activities like cleaning of bird's house, provision of supplementary feed and water ${ }^{[15]}$.

Similarly, ${ }^{[6]}$ declared that management of village chicken had been highly associated with women for various historical and social factors. [39] and [25] also reported that women and children were generally in charge of village chicken husbandry practices in developing countries. ${ }^{[1]}$ also reported that women and children involvement was by far the highest on village flocks management labor profile activities included; sheltering birds, cleaning bird's house, feeding and watering of birds in some parts of Nigeria and Cameroon. [29] also reported that women in Zimbabwe were dominated in most village chicken production activities like; feeding $(37.7 \%)$, watering $(51.2 \%)$ and cleaning of bird's house $(37.2 \%)$ whereas men were dominant in shelter constructions $(60 \%)$ and treatment of birds $(40 \%)$.

2.1.5. Village/backyard/ chicken flock size and structures Chicken production has occurred largely on small farmer holdings, with an average flock size of $4.1^{[8]}$, limited capital investment and few inputs provides an overview of chicken

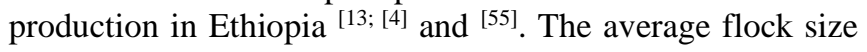
per household for hens, cocks, pullets, cockerels and young chicks was 3.3, 1, 2.3, 0.9 and 5.6, respectively; with a total flock size of 13 birds and a hen to cock ratio of $3.7: 1$. The average flock size per household varied between seasons mainly due to feed availability, the occurrence of diseases and predators ${ }^{[15]}$. Likewise, the chicks, hens and pullets $(80 \%)$ dominated the flock structure and were mainly retained for production purposes in Western Kenya ${ }^{[37]}$. On average households kept 23 chickens, two times higher than the reported average in Western Kenya ${ }^{[36]}$. Reduction of flock sizes may be the attribution of the limited availability of scavenging feed sources in Ethiopia. Currently, shortage of scavenging feed source is aggravated by reduced land sizes of the backyards, deforestation of the homesteads and lack of decomposition materials from the vicinity of the backyards in the country.

\section{Conclusion and Recommendation}

Poultry production in Ethiopia can be characterized into three major production systems, namely the large-scale commercial, the small scale commercial and the village or backyard poultry production system. Village/backyard/ chickens are predominantly produced under a scavenging, low input-output system and primarily used as the source of income and empowerment to the rural women and children. Chicken houses constructed from locally available materials and the dominant system of chicken feeding practiced in Ethiopia is free scavenging with supplementary feeding. Village/backyard/ chicken owners had no any culture of vaccinating birds against diseases in Ethiopia. This might be due to lack of awareness about the presence of chicken vaccines, lack of attention to free-range chickens and low availability of vaccines. All family members provided labor for chicken husbandry practices. Men were responsible for few activities like construction of shelter and taking sick birds 
for treatment. However, women were highly responsible for many activities like cleaning bird's house, feeding birds, selling birds and eggs. Currently, shortage of scavenging feed source is aggravated by reduced land sizes of the backyards, deforestation of the homesteads and lack of decomposition materials from the vicinity of the backyards in the country.

Therefore, the following recommendations are suggested for the sustainability of village/backyard/ chicken production system based on the result of the current review:-

- Technical interventions in village/backyard/ chicken production would include control of disease, improved feeding and watering, housing and introduction of marketoriented improved breeding practices to improve the genetic merits of the indigenous genetic resources through recurrent selection within the indigenous population and crossbreeding with exotic breeds.

- Provision of credit facilities to chicken owners for the enhancement of inputs, access to more profitable markets and training of farmers are the major interventions for enhancing the contribution of village chicken production to farmers' livelihoods.

- As most of village/backyard/ chicken production activitiesare managed by women and children, provision of successive trainings on modern chicken husbandry practices to women would be essential for the improvement of chicken production and productivity.

\section{References}

[1]. Abdelqader, A., Wollny, C. B. A. and Gauly, M., 2007. Characterization of local chicken production systems and their potential under different levels of management practice in Jordan, Tropical Animal Health and Production, 39, 155164http://dx.doi.org/10.1007/s11250-007-9000-x

[2]. Abubakar, M.B, A.G. Ambali and T. Tamjdo.2007. Rural Chicken Production: Effects of Gender on Ownership, and Management Responsibilities in Some Parts of Nigeria and Cameroon. International Journal of Poultry Science 6 (6): 413416.http://dx.doi.org/10.3923/ijps.2007.413.416

[3]. Alders R.2004. Poultry for profit and pleasure. FAO Diversification Booklet 3. Rome. Alders RG, Pym RAE. 2009. Village poultry: still important to millions, eight thousand years after domestication. World's Poult. Sci. J., 65:181. http://dx.doi.org/10.1017/s0043933909000117

[4]. Alemu,D. Alemu, T. Degefe, S. Ferede, S. Nzietcheung, D. Roy, 2008. Overview and Background Paper on Ethiopia's Poultry Sector: Relevance for HPAI Research in Ethiopia. DFID Pro-poor HPAI Risk Reduction Strategies Project Africa/Indonesia Region Report No. 1

[5]. Ayele, G. Ayele, D. Asare-Marfo, E. Birol, D. Roy. 2009. Investigating the Role of Poultry in Livelihoods and the Impact of HPAI in Ethiopia.
Controlling Avian Flu and Protecting People's Livelihoods in Africa and Indonesia. International Food Policy Research Institute (IFPRI) with the International Livestock Research Institute (ILRI) and Royal Veterinary College (RVC)

[6]. Bradley FA.1992. A historical review of women's contributions to poultry production and the implications for poultry development process. In: Proceedings of the 19th World's Poultry Congress, Amsterdam, the Netherlands. pp. 693-696.

[7]. Branckaert, R.D.S. and Guéye. 1999. FAO's Programme for Support to family poultry production. In: Proceedings workshop on poultry as a tool inpoverty eradication and promotion of gender equality held March 22 to 26, 1999. Denmark.

[8]. CSA (Central Statistical Agency). 2005. Agricultural Sample Survey 2004/05. Central Statistical Authority No. 2. Report onLivestock and livestock characteristics. Stat. Bull. P. 331.

[9]. CSA (Central Statistical Agency). 2011 Agricultural sample survey 2010/11, 2: statistical bulletin 505 . Report on livestock and livestock characteristics (prevent peasant holdings), Addis Ababa, February 2011.21.

[10]. CSA (Central Statistical Agency). 2013. Agricultural sample survey 2012/13. Report on livestock and livestock characteristics, Statistical Bulletin Addis Ababa, Ethiopia. 2:570. Dana, N. 2011. Breeding programs for indigenous chicken of Ethiopia. PhD thesis. Wageningen, the Netherlands: Wageningen University.

[11]. Desalew Tadesse, Harpal Singh, Ashenafi Mengistu, Wondimeneh Esatu and Tadelle Dessie. 2013. Study onmanagement practices and marketing systems of villagechicken in East Shewa, Ethiopia

[12]. Dessie, T., Esatu, W., Waaij, L.V., Zegeye, F., gizaw,S., Mwai, O. and van Arendonk, J. 2013. Villagechicken production in the central and western highlandsof Ethiopia: characteristics and strategies forimprovement. Nairobi, Kenya: International livestockResearch institute.

[13]. FAO (Food and Agriculture Organization of theUnited Nations). 2004. Egg marketing. A guidefor the production and sale of eggs. FAO, Rome,Italy.

[14]. FAO (Food and Agriculture Organization of the United State Nations). 1997. Guidelines for the inclusion of improved household poultry production. Diversification component of the special programme for food security, Rome. pp: 86

[15]. Fisseha Moges, Abera Mellesse and Tadelle Dessie. 2010. Assessment of village chicken production system and evaluation of the productive and reproductive performance of local chicken ecotype 
in Bure district, North West Ethiopia. African Journal of Agricultural Research Vol. 5(13), pp. 1739-1748

[16]. Gezahegn, A. and Rich, K.M. 2010. Poultry value chains and HPAI in Ethiopia. Africa/Indonesia Team Working Paper 25. Washington, DC, USA: International Food Policy Research Institute (IFPRI).

[17]. Gizaw, S., Awigchew, K. and Yami, A. 2011. A practical guide for village-based sheep and goat cooperative breeding scheme. ESGPIP Technical Bulletin 42. Addis Ababa, Ethiopia: ESGPIP.

[18]. Glatz Phil and Yingjun. 2004. Developing freerange animal production systems. A report for the Australian Government Rural Industries Research Development Corporation. Pp 4-23

[19]. Gondwe, T.N.P., 2004. Characterization of local chicken in low input-low output production systems: is there scope for appropriate production and breeding strategies in Malawi? PhD Thesis. GeorgAugust- Universität Göttingen, Germany.

[20]. Gueye, E.F. 1998. Village egg and fowl meat production in Africa, World's Poultry Science Journal, $\quad 54, \quad 73-86$ http://dx.doi.org/10.1079/wps19980007

[21]. Halima. H.2007. Phenotypic and Genetic Characterization of Indigenous Chicken Populations in Northwest Ethiopia. PhD Thesis; University of the Free State, Bloemfontein, South Africa. P. 186.

[22]. Hellin J, Griffith A, Mike A. 2005. Mapping the market: Market-literacy for agricultural research \& policy to tackle rural poverty in Africa. In: Proceedings of an International Seminar, 28th February 1st March 2005, Westminster, London, UK, pp. 110-150.

[23]. Huque QME, Paul DC. 2001. Strategies for family poultry production with special reference to women participation. Paper presented in $1^{\text {st }}$ SAARC Poultry Conference held on 24-26, September. Pune, India.www.cipav.org.co/lrrd/lrrd9/3/bang931.htm.

[24]. Jens Christian R, Anders P, Charlotte V, Ainsh MC, Lone F. 2004. Keeping Village Poultry. A technical manual for small-scale poultry production. Copenhagen, Denmark.

[25]. Kitalyi A.1998. Village chicken production systems in rural Africa. Household's food and gender issues. Food and Agriculture Organization of the United Nations: Rome Italy. P.81

[26]. Kusina J, Kusina NT, Mhlanga J. 2000. A Survey on Village Chicken Losses: Causes and Solutions as perceived by farmers in communal area of Zimbabwe. Accessed on 27th August, 2007.

[27]. Lwesya H, Phoya RKD, Safalaoh ACL, Gondwe TNP. 2004. Rearing chicks in enclosures under village conditions: effect on growth and reproductive performance of hens. Livestock Res. Rural Dev., 16:11.

[28]. Mandal MK, Khandekar N, Khandekar P. 2006. Backyard poultry farming in Bareilly district of Uttar Pradesh, India: an analysis. Livest. Res. Rural Dev., 18. Art. \# 7 . http://www.lrrd.org/lrrd18/7/mand18101.htm

[29]. Mapiye, C. and S. Sibanda. 2005. Constraints and opportunities of village chicken production systems in the smallholder sector of Rushinga District of Zimbabwe. Livestock Res. Rural Dev. 17 (10). http://www.cipav.org.co/lrrd/lrrd17/10/mapi17115. htm. Accessed: 04/11/2005.

[30]. Melesse A, Negesse T. 2009. Study on the characterization of local chickens found in Southern Ethiopia. In: Proceedings of Annual Research Review Workshop, Awassa University, Awassa, Ethiopia, May 16-17. Pp.1-15.

[31]. Mengesha M, Tamir B, Dessie T. 2011. Village Chicken Constraints and Traditional Management Practices in Jamma District, South Wollo, Ethiopia. Livestock research for Rural Development. Volume 23, Article \#37. Retrieved February 5, 2013, from http://www.lrrd.org/lrrd23/2/meng23037.htm

[32]. Mengesha M, Tamir B, Dessie T. 2012. Village Chicken Constraints and Traditional Management Practices in Jamma District, South Wollo, Ethiopia. Livestock Research for Rural Development. Volume 23, Article \#37. Retrieved February 5, 2013, from http://www.lrrd.org/lrrd23/2/meng23037.htm.

[33]. Mlozi MRS, Kakengi AVM, Minga UM, Mtambo AM, Olsen JE. 2003. Marketing of free range local chicken in Morogoro and Kilosa urban markets, Tanzania. Livestock Res. Rural Dev., 15:2.

[34]. Moges F, Abera M, Tadelle D. 2010. Assessment of village chicken production system and evaluation of the productive and reproductive performance of local chicken ecotype in Bure district, North West Ethiopia. Afr. J. Agric. Res. 5(13):1739-1748.

[35]. Muchadeyi FC, Sibanda S, Kusina NT, Kusina J, Makuza S. 2004. The village chicken production system in Rushinga District of Zimbabwe. Livest. Res. Rural Dev., 16. Art. \# 6.

[36]. Njue, S. W., Kasiiti, J. L. \& Gacheru, S. G.2006. Assessing the economic impact of commercial poultry feeds supplementation and vaccination against Newcastle disease in local Chicken in Kenya. Proceedings of a final research coordination meeting organized by the Joint FAO/ International Atomic Energy Agency (IAEA) held in Vienna, 2428 May 2004.

[37]. Ochieng Justus, George Owuor, Bockline Omedo Bebe. 2013. Management practices and challenges 
in smallholder indigenous chicken production in Western Kenya. Journal of Agriculture and Rural Development in the Tropics and Subtropics Vol. 114 No. 1 (2013) 51-58

[38]. Pedersen CV.2002. Production of semi-scavenging chickens in Zimbabwe. Ph.D Thesis. Royal Veterinary and Agricultural University, Copenhagen, Denmark.

[39]. Riise JC, Permin A, Kryger KN.2004. Strategies for developing family poultry production at village level. Experiences from West Africa and Asia. Network for Smallholder Poultry Development, Dyrlaegevej Frederiksberg, Denmark. 2:1870.http://dx.doi.org/10.1079/wps200437

[40]. Robert JA. 1992 The scavenging feed resource base in assessment of the productivity of scavenging chickens. Newcastle disease in village chickens, control with thermo stable vaccine. In: Proceedings of ACIAR, No. 39, Canberra, Australia. pp. 29-32.

[41]. Safalaoh ACL. 2001. Village Chicken Upgrading Programme in Malawi.World's Poult. Sci. J., 57:179-188. http://dx.doi.org/10.1079/wps20010013

[42]. Salam KR. 2005. Improvement of village chicken production in a mixed (chicken-ram) farming system in Burkina Faso. Ph.D Thesis. Wageningen Institute of Animal Sciences, Animal Nutrition Group, Wageningen University, the Netherlands.

[43]. Samson L, Endalew B. 2010. Survey on Village Based Chicken Production and Utilization System in Mid Rift Valley of Oromia, Ethiopia. Global Vet., 5 (4): 198- 203.

[44]. Serkalem T, Hagos A, Zeleke A. 2005. Seroprevalence study of Newcastle disease in local chickens in central Ethiopia. Inter. J. Appl.Res. Vet. Med., 3:1.

[45]. Sonaiya EB, Swan SEJ. 2005. Small-scale poultry production, technical guide manual. FAO Animal Production and Health 1. Food and Agriculture Organization of the United Nations (FAO), Rome.

[46]. Sonaiya, E.B. 1990. Toward sustainable poultry production in Africa. In: Paper presented at the FAO expert consultation on strategies for sustainable animal agriculture in developing countries, Rome, Italy.

[47]. Tadelle D, Million T, Alemu Y, Peters K. 2003. Village chicken production systems in Ethiopia: Use patterns and performance valuation and chicken products and socio-economic functions of chicken.

[48]. Tadelle D, Million T, Alemu Y, Peters KJ. 2003b. Village chicken production systems in Ethiopia: 2. Use patterns and performance valuation and chicken products and socio-economic functions of chicken; Livestock Research for Rural Development (15) 1.
Retrieved February 5, 2013, from

[49]. http://www.lrrd.org/lrrd15/1/tadeb151.htm.

[50]. Tadelle D, Million T, Alemu Y, Peters KJ. 2003a. Village chicken production systems in Ethiopia: 1. Flock characteristics and performance; Livestock Research for Rural Development (15) 1.Retrieved February5, 2013,

[51]. fromhttp://www.lrrd.org//rrd15/1/tadea151.htm

[52]. Tadelle D.2002. Phenotypic and genetic characterization of chicken ecotypes in Ethiopia. PhD thesis. Humboldt University, Germany. 208 pp.

[53]. Tadelle Dessie, Ogle B. 2001. Village poultry production system in the Central Highlands of Ethiopia. Trop. Anim. Health Prod. 33:521537.

[54]. http://dx.doi.org/10.1023/a:1012740832558

[55]. Takele T, Oli W. 2011. Uses and flock management practices of scavenging chickens in Wolaita Zone of southern Ethiopia. Trop. Anim. Health Prod 44:537544. 9933-y http://dx.doi.org/10.1007/s11250-011-

[56]. Teketel Forsido. 1986. Studies on the meat production potential of some local strains of chicken in Ethiopia. Ph.D Thesis. J.L.University of Giessen, Germany. 210 p.

[57]. USAID (United States Agency for International Development). 2010. Partnership for safe poultry in Kenya (PSPK) program: Value chain analysis of poultry in Ethiopia. Addis Ababa, Ethiopia: USAID.

[58]. Wilson RT. 2010. Poultry production and performance in the Federal Democratic Republic of Ethiopia. World's Poult. Sci. J. 66:441454.http://dx.doi.org/10.1017/s0043933910000528 